\title{
UM DEPOIMENTO SOBRE O ESTUDO JURÍDICO
}

Chamo-me Fábio de Weimar Thé Filho e sou um ex-aluno do bacharelado em Direito da Universidade Federal Rural do Semi-Árido (UFERSA). Ingressei nos corredores desta em abril de 2014 (semestre 2014.1) e despedi-me deles colando grau em abril de 2019 (semestre 2019.1). Passei exatos cinco anos nessa Instituição fantástica, que foi a responsável por transformar a minha vida e ampliar maravilhosamente os meus horizontes.

Desde o início do curso, tinha a certeza de que estava no local certo, assim como estava rodeado pelas pessoas certas. As cadeiras propedêuticas lecionadas nos dois primeiros períodos reformularam meus pensamentos por meio da leitura dos grandes clássicos da sociologia e filosofia. Foram trabalhos, resumos e artigos que me garantiram um arcabouço crítico para uma melhor atuação enquanto operador do Direito. Destaco, também de grande importância, as várias apresentações orais que, a princípio, me causavam tanto espanto e desconforto, mas que, ao final, me serviram como valiosos momentos para a perda da timidez, desenvolvimento da oratória e aumento da autoconfiança.

Após, iniciaram-se as cadeiras dogmáticas, o que me cativou ainda mais. O fascínio pelas diversas searas jurídicas e a sede pelo conhecimento brotaram em mim de maneira surpreendente, pois em nenhum outro ramo do saber eu havia desejado alcançar tanto conhecimento. Os fundamentos do Direito Constitucional, os princípios do Direito Penal e as várias nuances do Direito Administrativo me faziam ter a certeza de que nenhum outro curso de graduação me traria tanta satisfação.

O contato com os brilhantes professores da Instituição facilitava ainda mais a absorção do conteúdo. Em especial, faço menção ao Mestre Albenes, com suas fantásticas aulas de Processo Civil, bem como de Mediação e Arbitragem. De fato, as lições apreendidas nesta última cadeira me foram importantes não apenas como graduando, mas edificaram também a minha pessoa, me fazendo crescer enquanto ser humano pacificador de conflitos.

Com o passar dos períodos, chegou o momento de ter o convívio prático com a Lei. O estágio em diversos órgãos públicos (tais quais Ministério Público Federal, Ministério Público Estadual e Procuradoria Geral do Estado), além do Núcleo de Práticas Jurídicas, me fez conhecer um novo quadrante do Direito. Acima de tudo, compreendi o real valor do contraditório: antes de acusar ou tomar qualquer decisão em favor ou desfavor de alguém, é necessário garantir que os envolvidos sejam ouvidos, pois lhes retirar tal seria atentar contra todo o Estado Democrático. Vislumbrar no mundo dos fatos a nocividade de um processo inquisitivo foi muito mais valioso para mim do que ler centenas de páginas escritas por notáveis autores a respeito de princípios processuais. 
Paralelamente a isso, sempre objetivei minha aprovação em concursos públicos e, para alcançar êxito nessa empreitada, passei a direcionar cada vez mais os meus estudos. Após várias reprovações, fui aprovado no final do sexto semestre para o cargo de Técnico Judiciário no Tribunal de Justiça de Pernambuco, função que ocupo até hoje.

Já na reta final da faculdade, chegou a época de prestar o Exame da Ordem dos Advogados do Brasil (OAB), no qual a UFERSA coleciona brilhantes índices de aprovação, destaco. Uma graduação bem aproveitada, aliada a um direcionamento de reta final de estudos, são o bastante para conseguir ingressar no campo da advocacia.

Simultaneamente, era o momento de apresentar o Trabalho de Conclusão de Curso. Por ter iniciado a elaboração do meu escrito um semestre antes, me livrei de diversos contratempos que os concluintes normalmente enfrentam. Desse modo, se tivesse que sugerir algo neste espaço para os discentes do curso, diria para colocarem prioridade nessa tarefa.

Antecipando algumas cadeiras, consegui colar grau um semestre antes do previsto. O sentimento era uma mescla de alívio por poder me dedicar de forma exclusiva aos meus estudos, e de saudade dos professores, colegas e dos felizes momentos que vivi naquele bloco de Direito.

Em síntese, posso afirmar que entrei na UFERSA como um adolescente de dezessete anos com um minúsculo universo de vivência e conhecimento, e saí como um cidadão conhecedor das leis (na medida do possível, ressalto) e um ser humano sensível às necessidades e sentimentos alheios. Tudo isso apenas foi possível graças à educação pública e de qualidade ofertada pela minha querida Universidade Federal Rural do Semi-Árido. 